\title{
CORRECTION
}

View Article Online

View Journal I View Issue

(1) CrossMark

Cite this: RSC Adv., 2015, 5, 64300

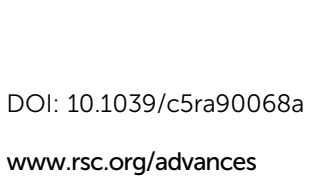

\section{Correction: Highly selective aluminium-catalysed intramolecular Prins reaction for L-menthol synthesis}

\author{
H. Itoh, ${ }^{\text {ab }}$ H. Maeda, ${ }^{a}$ S. Yamada, ${ }^{a}$ Y. Hori, ${ }^{* a}$ T. Mino $^{\star b}$ and Masami Sakamoto ${ }^{b}$
}

Correction for 'Highly selective aluminium-catalysed intramolecular Prins reaction for L-menthol synthesis' by H. Itoh et al., RSC Adv., 2014, 4, 61619-61623.

The authors regret that, due to mistakes in the analysis of NMR data, incorrect structures were presented in Table 2 of the original manuscript for the cyclization products $\mathbf{1 4}, \mathbf{1 6}$ and 18. The correct structures are given in the amended version of Table 2 , which is shown below.

Table 2 The Prins reaction of a variety of substrates with ACPP (4b)

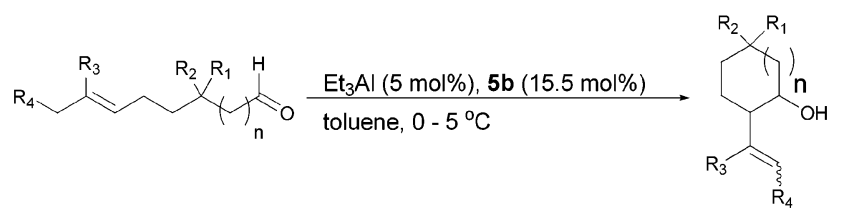

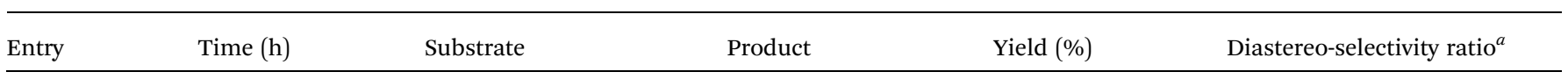

$1^{b}$

19

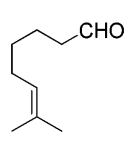

7

1

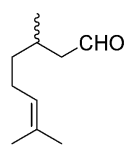

$( \pm)-1$

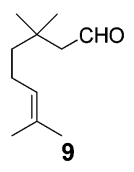

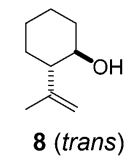<smiles>C=C(C)C1CCCCC1O</smiles>

$29^{a}$

trans $/$ cis $=81 / 19$ (cis)<smiles>C=C(C)[C@H]1CCC(C)CC1O</smiles>

92 $( \pm)-2 a /( \pm)-2 b, 2 c, 2 d=98.9 / 1.1$

$( \pm)-2 a$<smiles>CC(C)=C(C)C1CCC(C)(C)CC1O</smiles>

10 
Table 2 (Contd.)
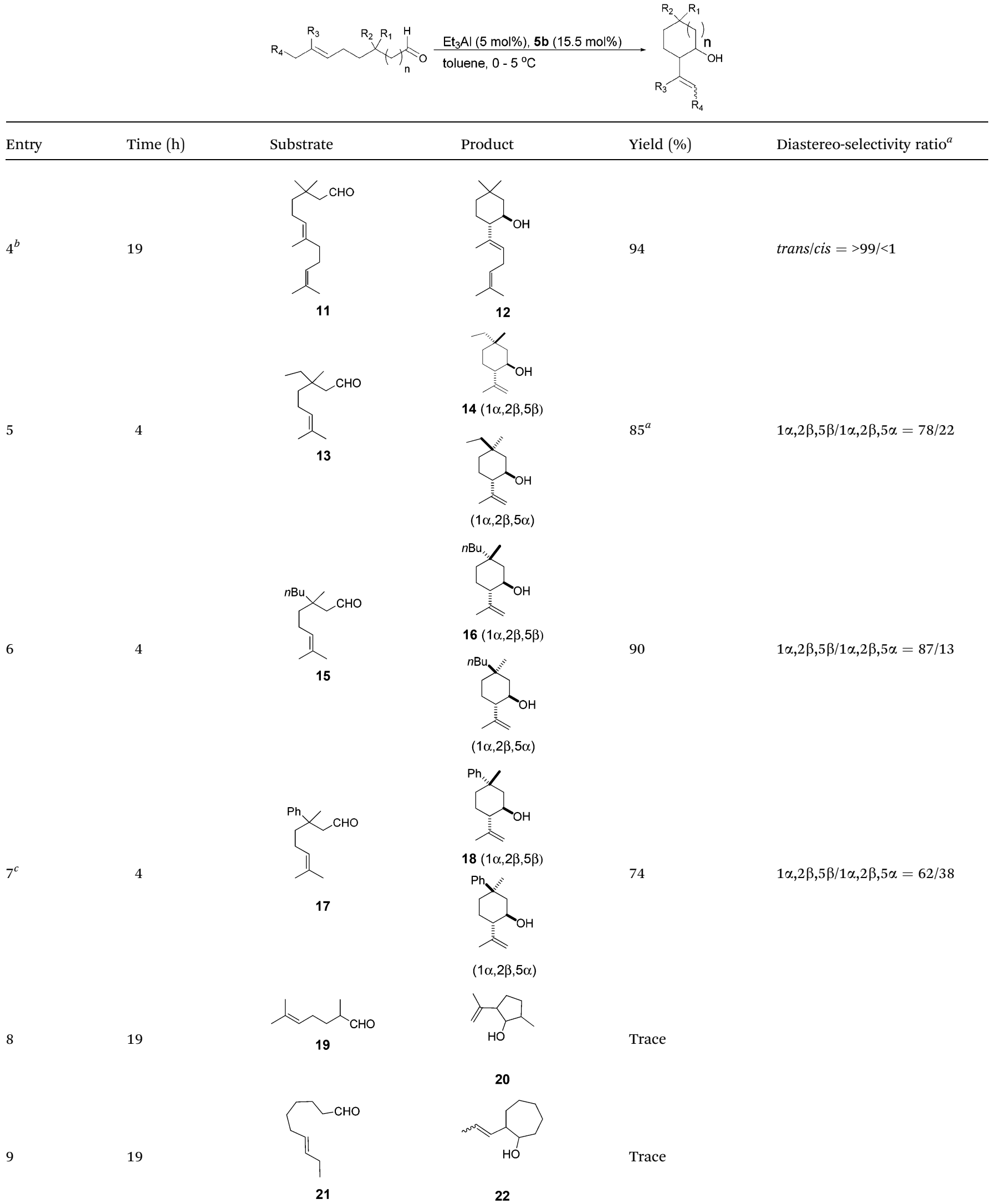

${ }^{a}$ Determined by gas chromatography (GC) analysis. ${ }^{b} \mathrm{Et}_{3} \mathrm{Al}(20 \mathrm{~mol} \%)$ and $\mathbf{5 b}(62 \mathrm{~mol} \%)$ were used. ${ }^{c} \mathrm{Et}_{3} \mathrm{Al}(10 \mathrm{~mol} \%)$ and $\mathbf{5 b}(31 \mathrm{~mol} \%)$ were used. 
The Supplementary Information for the original article has been updated to show the correct structures.

The Royal Society of Chemistry apologises for these errors and any consequent inconvenience to authors and readers. 